\title{
Important Meroplankton: Zoea and Megalopa of Pinnotherid Crab Pinnixa rathbuni*
}

\section{Short Paper}

From Japanese waters only 5 species have been reported, two of which were found by SAKAI ${ }^{1)}$ in Ise Bay on the Pacific coast of central Japan; namely $P$. rathbuni and $P$. balanoglossano. One of the most peculiar phenomena met with in Japanese waters is the abundance of $P$. rathbuni amongst the Pinnixa species ${ }^{2,32}$. This small carb is one of the most popular benthos and so important foods for demersal fishes in Ise Bay. It occurs at gravel, sand and sand-mud bottoms on the western shore and near the mouth of the bay, but has never been found at mud bottom, nor appears on the northern and the eastern shores as well as in the central part of the bay. ${ }^{2}$ )

$P$. rathbuni has been considered to breed during the period from early summer to autumn, to have free-living zoea and megalopa, and to turn to a benthic phase of life from February to June in Sendai Bay ${ }^{3}$. Abundant zoea and megalopa of $P$. rathbuni were met with only in plankton samples taken from Ise Bay from November to February (Fig. 1). The larvae of this small crab constituted 1.7 to $58.4 \%$ in wet weight of zooplanktons collected from November to February. Of the two peaks of zooplankton biomass in spring and winter, repeatedly observed every year in the bay ${ }^{5,0}$, the maximal weight of zooplankton in January was supported by the larvae of this small crab and chaetognaths (mainly $S$. crassa). This means that the larvae of this small crab would be one of the most important zooplankton during autumn and winter in the bay as well as chaetognaths, which occupied 7.3 to $34.6 \%$ of zooplankton weights collected from November to February in the bay.

The free-living zoea and megalopa were obtained from the whole bay differently from a benthic phase of life. The number of individuals reached a peak of mean 166 inds. $/ \mathrm{m}^{8}$ ( $\max .1100$ inds. $/ \mathrm{m}^{8}$ ) in January (Fig. 1). Almost all of the larvae of the crab in February were megalopa stages. Judging from the decrease of individual numbers in February, it is suggested that mortality of zoea stages would be considerable in contrast with that of megalopa stages.

Received July 29, 1976

*重要な定期性ブランクトンカクレガ二幼生 (関口秀夫：三重大学水産学部).
It will be an interesting problem to inquire into food-webs in zooplankton community in autumn and winter, because the larvae of the crab are typically carnivorous as another dominant chaetognath $S$. crass is. The larvae of the crab has never been found in stomach contents of the spawners of sand-eels, caught near the mouth of the bay, whereas Calanus and Sagitta are preyed abundantly by sand-eels.

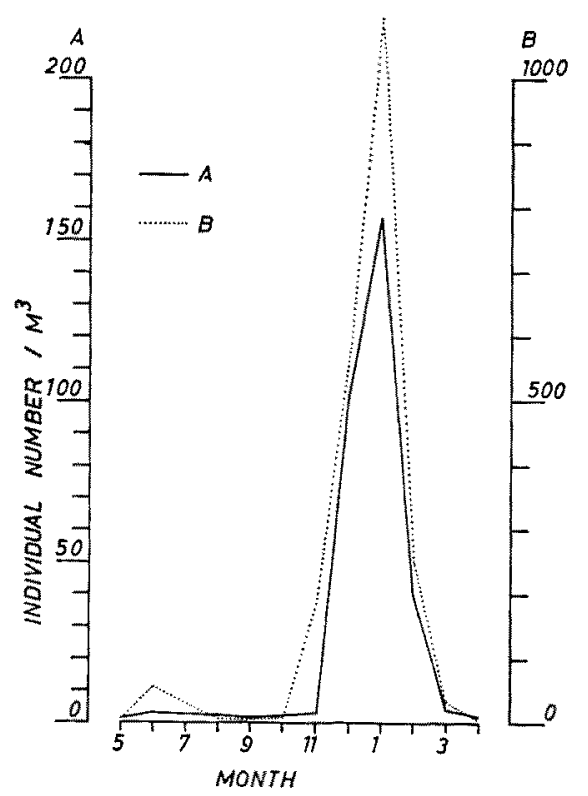

Fig. 1. Seasonal change of individual number per cubic meter of free-living larvae of $P$. rathbuni in Ise Bay.

$A$ : average individual number;

B: maximal individual number.

Hideo SEKı IGUChI

Faculty of Fisheries, Mie University 2-80 Edobashi, Tsu, Mie, Japan

\section{References}

1) T. Sakal: Sci. Rep. T. B. D. Sect. B., 2, 37-43 (1934).

2) D. Mryadi: Memoirs Imperial Mar. O£ser., 7, 503-524 (1941).

3) M. OMorI: This Bull., 40, 1115-1126 (1974).

4) O. W. Hyman: Proc. U. S. Nat. Mus., 64, 1-9 (1924).

5) H. SuzukI: Bull. Jap. Soc. Fish. Oceanogr., 16, 150-155 (1970).

6) H. SekiguchI: This Bull., 43, 123-127 (1977). 